\title{
Impacts of Untreated Sewage Discharge on Water Quality of Middle Manyame River: A Case of Chinhoyi Town, Zimbabwe
}

\author{
Muisa Norah*, Zingundu Shumirai, Mangori Lynda Zelma, Mupfiga Upenyu \\ Chinhoyi University of Technology, Environmental Science and Technology Department, Chinhoyi, Zimbabwe \\ Email address: \\ norahmuisa@yahoo.co.uk (M. Norah), shumiraizingundu@gmail.com (Z. Shumirai), lyndamangori@gmail.com (M. L. Zelma), \\ nyatondou@gmail.com (M. Upenyu)
}

\section{To cite this article:}

Muisa Norah, Zingundu Shumirai, Mangori Lynda Zelma, Mupfiga Upenyu. Impacts of Untreated Sewage Discharge on Water Quality of Middle Manyame River: A Case of Chinhoyi Town, Zimbabwe. International Journal of Environmental Monitoring and Analysis.

Vol. 3, No. 3, 2015, pp. 133-138. doi: 10.11648/j.ijema.20150303.14

\begin{abstract}
Disposal of untreated sewage into surface waters is common in most developing countries. Any physico-chemical, or biological condition that prevents the designated uses of a water body represents poor water quality. This study was carried out on Middle Manyame River, a major source of potable water in Chinhoyi town. The study sought to ascertain the impacts of discharging untreated sewage on the water quality of Middle Manyame River. The following parameters were determined using APHA standard methods; nitrates, phosphates, $\mathrm{pH}$, temperature, dissolved oxygen (DO), total dissolved solids (TDS), and biological oxygen demand (BOD). Sampling was done in November 2013, March 2014, and May 2014. All the parameters, except for $\mathrm{pH}$ and temperature, exceeded acceptable water quality standards for the sites downstream of the sewage discharge points. This indicated that the improper sewage discharge was the major contributor to poor water quality, among other activities such as agricultural runoff. It was concluded from the study that sewage effluent from the Municipality of Chinhoyi sewage works was mainly responsible for pollution along Middle Manyame River. This pollution has also put the river at risk of eutrophication. It was recommended that there should be rehabilitation and upgrading of sewage systems in Chinhoyi.
\end{abstract}

Keywords: Middle Manyame River, Chinhoyi, Sewage, Water Quality, Eutrophication

\section{Introduction}

Most aquatic ecosystems around the world, especially rivers, lakes and reservoirs, have been polluted by untreated domestic sewage/wastewater, mining waste, industrial wastewater, agricultural waste, and other pollutants [1]. This is due to extensive industrialization, increasing population density and high urbanized societies [2]. The disposal of untreated or poorly treated sewage into surface water bodies in urban areas is common in most developing countries, including Zimbabwe [3-5]. With the prevailing harsh economic situation in the country, most of the trade waste effluents are released into the environment untreated or partially treated [6]. With the current emphasis on environmental health and water pollution issues, there is an increasing awareness of the need to dispose of wastewaters safely and beneficially.

Discharge of untreated or partially treated sewage water in surface water bodies can lead to contamination of upper soil surfaces, sewage drainage facilities, surface water, and groundwater [3]. The nutrients, nitrogen and phosphorous, are dominant in these municipal discharges, posing a great risk of eutrophication-related problems to the receiving waterbodies [5, 7]. Eutrophication leads to algal blooms and plant growth in streams, ponds, lakes, reservoirs and estuaries and along shorelines [8]. In lakes, rivers, streams, and coastal waters where large algal blooms are present, the death of the vast numbers of phytoplankton that make up the blooms may smother the lake bottom with organic material. The decay of this material can consume most or all of the dissolved oxygen in the surrounding water, thus threatening the survival of many species of fish and other aquatic life [9]. In addition, sewage effluent poses a great burden in terms of wastewater management and can consequently lead to a point-source pollution problem, which not only increases water treatment costs considerably, but also introduces a wide range of chemical pollutants and microbial contaminants to water source [10]. As explained by [11], all 
these effects of improper discharge of sewage effluent into surface waters will ultimately reduce the potential of concerned water bodies becoming water resources.

The direct discharge of poorly treated sewage effluents, that are rich in nitrogen and phosphorous, into aquatic systems has been clearly shown to be a major cause of eutrophication problems in the country. This has been shown, particularly, for those water bodies located close to major urban centres such as Chinyika River, Manyame River, Mukuvisi River and Lake Chivero [12] and [13]. This study was centered on Manyame River, which is the largest water source to the town of Chinhoyi, focusing on the impacts of untreated sewage discharges on the river. The Municipality of Chinhoyi is responsible for wastewater treatment in Chinhoyi and has four wastewater treatment plants all of which are non-functional, resulting in dumping of raw sewage into Manyame River. Chinhoyi Municipality has designed channels which dispose sewage directly into Manyame River. It is for this reason that the study investigated the impacts of untreated sewage discharge on the water quality of Middle
Manyame River in order to ascertain its contribution towards eutrophication.

\section{Materials and Methods}

\subsection{Description of Study Area and Sampling Points}

Chinhoyi town is the regional capital for Mashonaland West Province, which is one of the seven provinces in Zimbabwe. Chinhoyi town is located approximately $114 \mathrm{~km}$ North West of the capital city, Harare, (Fig.1). According to the 2012 National Census given in [14], Chinhoyi town has an estimated population of 79368 people. It is under municipal jurisdiction, with the administrative boundaries flanked by commercial agricultural farms. It has an average annual temperature of around $24.5^{\circ} \mathrm{C}$. Chinhoyi Town experiences the following monthly average weather conditions; highest temperature in October at $31^{\circ} \mathrm{C}$, minimum temperature in July at less than $5^{\circ} \mathrm{C}[6]$.

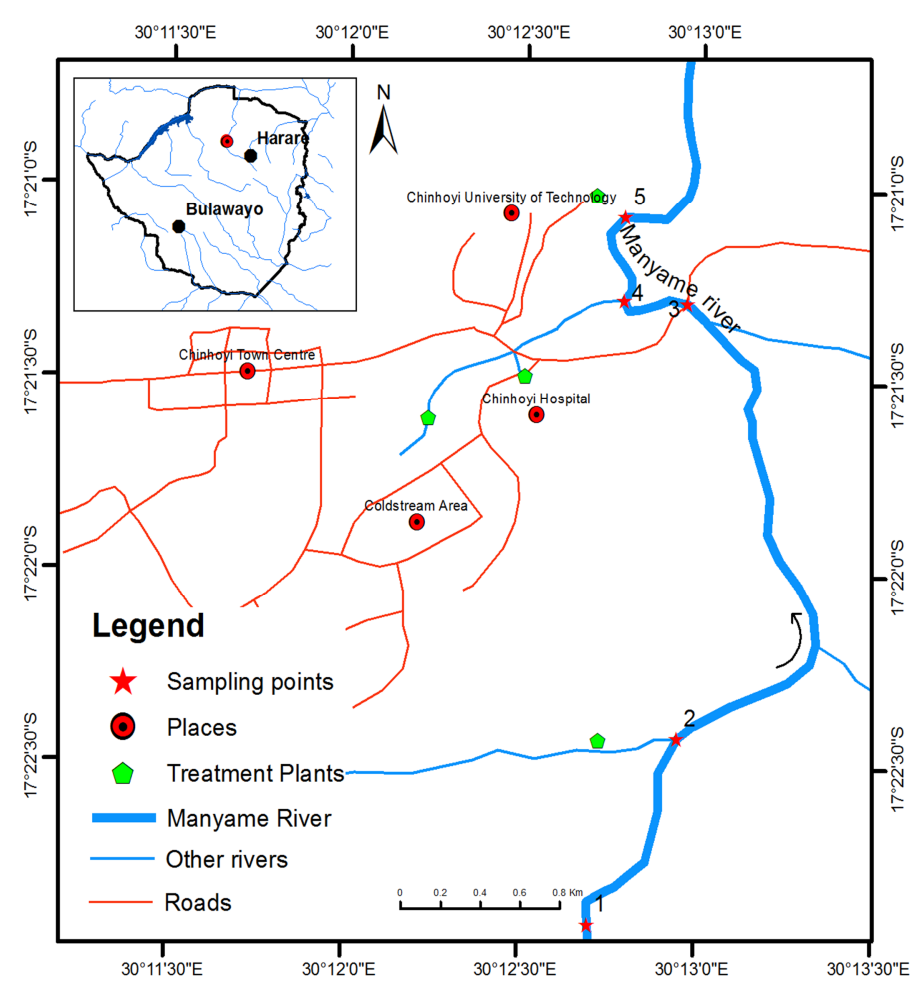

Figure 1. Map showing the position of Chinhoyi town, the various sewage effluent discharge points and the sampling sites in the river.

January is the wettest month recording $225 \mathrm{~mm}$ rainfall on average and July is the driest month with the least precipitation of less than $10 \mathrm{~mm}$. The town experiences two distinct seasons which are summer from October to April and winter from May to September.

The main source of potable water for Chinhoyi town is Manyame River that flows through the town on the eastern side supplying water for domestic, industrial, and agricultural use. The town is built on a rugged and hilly terrain bisected by many streams that drain into Manyame River. Manyame River rises near the Marondera town about $65 \mathrm{~km}$ east of
Harare, flows in an east - west direction until it reaches Lake Cabora-Bassa on the Zambezi River in Mozambique [15]. Manyame River is one of the country's major rivers and Chinhoyi is located in the Middle Manyame Catchment.

The sampling points were selected as described in Table 1 . The sampling sites are numbered from 1 to 5 in the study area map, whereby 1, 2, 3, 4 and 5 are US, MTP, MB, CTP, and FTP, respectively. Only the effluent from CTP could be sampled and thus acted as a representative of the effluent being discharged by the other three treatment plants. 
Table 1. Description and justification of selection of sampling points.

\begin{tabular}{|c|c|c|}
\hline Sampling site & $\begin{array}{l}\text { Approx. distance } \\
(\mathrm{km})\end{array}$ & Description/ Justification \\
\hline $\begin{array}{l}\text { Control Upstream } \\
\text { (US) }\end{array}$ & $\begin{array}{l}1.5 \mathrm{~km} \text { upstream of } \\
\text { MTP }\end{array}$ & $\begin{array}{l}\text { Acted as control site. } \\
\text { Located upstream of first } \\
\text { discharge point at MTP, } \\
\text { with little or no interaction } \\
\text { with raw sewage }\end{array}$ \\
\hline $\begin{array}{l}\text { Mpata treatment } \\
\text { plant (MTP) }\end{array}$ & $\begin{array}{l}0.05 \mathrm{~km} \text { after } \\
\text { discharge point }\end{array}$ & $\begin{array}{l}\text { Used to show immediate } \\
\text { impacts of the } \\
\text { discharge from MTP on } \\
\text { river water quality }\end{array}$ \\
\hline $\begin{array}{l}\text { Manyame Bridge } \\
(\mathrm{MB})\end{array}$ & $2.5 \mathrm{~km}$ from MTP & $\begin{array}{l}\text { Important to show any } \\
\text { possible dilution ability or } \\
\text { self purification capacity } \\
\text { along the river. }\end{array}$ \\
\hline $\begin{array}{l}\text { Coldstream } \\
\text { Treatment plant } \\
(\mathrm{CTP})\end{array}$ & $0.05 \mathrm{~km}$ from CTP & $\begin{array}{l}\text { Used to show immediate } \\
\text { impacts of the discharge } \\
\text { from CTP on river water } \\
\text { quality. }\end{array}$ \\
\hline $\begin{array}{l}\text { Coldstream } \\
\text { Treatment plant } \\
\text { (CTP Effluent) }\end{array}$ & $\begin{array}{l}\text { Outlet in effluent } \\
\text { channel }\end{array}$ & $\begin{array}{l}\text { This point was the raw } \\
\text { effluent before mixing with } \\
\text { river water. Acted as a } \\
\text { representation of municipal } \\
\text { discharges in Chinhoyi. }\end{array}$ \\
\hline $\begin{array}{l}\text { Fernlea treatment } \\
\text { plant (FTP) }\end{array}$ & $\begin{array}{l}0.05 \mathrm{~km} \text { after FTP } \\
\text { discharge point }\end{array}$ & $\begin{array}{l}\text { Used to show immediate } \\
\text { impacts of the discharge } \\
\text { from FTP on river water } \\
\text { quality. }\end{array}$ \\
\hline
\end{tabular}

\subsection{Sample Collection and Frequency}

Samples of water were collected once in the months of November 2013, March 2014, and May 2014. November represented dry weather conditions whilst March and May represented wet weather with the later occurring well after the rainy season. Composite samples, each made up of 3 grab samples (at the middle and opposite edges of that sampling point), were collected using $2 \mathrm{~L}$ polythene containers. The containers were rinsed three times with the sample water before filling them with the actual sample. The samples were collected about $20 \mathrm{~cm}$ beneath the water surface to avoid collecting any suspended materials. The samples were stored in a cooler box until they were tested in the laboratory within 24 hours.

\subsection{Field Analyses}

The river water $\mathrm{pH}$, temperature and dissolved oxygen (DO) were tested in the field using a $\mathrm{pH}$ meter, a mercury bulb thermometer and a dissolved oxygen meter, respectively. The WTW-pH/cond 340i pH meter was pre-calibrated using buffer solutions of $\mathrm{pH} 4$ and 7. The $\mathrm{pH}$ and DO meters were immersed into each water sample and reading was only recorded after the meters had stabilized.

\subsection{Laboratory Analyses}

The biological oxygen demand (BOD) of each sample was measured using the Winkler method whilst the gravimetric method was used for total dissolved solids (TDS) as described in [16]. The UV - VIS Spectrophotometer was used to measure the levels of nitrates and phosphates in each sample according to standard methods [16].

\subsection{Data Processing and Analysis}

SPSS 20.0 for Windows (SPSS Inc.) was used for statistical data analysis. One Way Analysis of Variance (ANOVA) was used to determine statistical differences among sampling points and campaigns.

\section{Results and Discussion}

\subsection{Characteristics of Cold Stream Sewage Treatment Plant Effluent (CTP effluent) as a Representation of Effluent Discharges in Chinhoyi Town}

Table 2 shows the typical quality of the effluent that is being generated in the Town of Chinhoyi and discharged into Manyame River. Of the parameters tested, only temperature and $\mathrm{pH}$ were within the permitted ranges, as stipulated by the Government of Zimbabwe Statutory Instrument (S.I) 274 of 2000, that is, [17] for discharge of effluent into surface waters. According to the effluent classification system used in the country as provided by [17], the effluent being discharged into Middle Manyame River is in the medium range which indicates that if the effluent is discharged into surface water it may have adverse effects on the receiving water quality.

Table 2. A snapshot of characteristics of sewage effluent discharged into Middle Manyame River from Chinhoyi Town; a case of Coldstream treatment plant.

\begin{tabular}{llllll}
\hline Parameter & Unit & November & March & May & $\begin{array}{l}\text { ZINWA, } \\
\mathbf{2 0 0 0}\end{array}$ \\
\hline Temperature & $\begin{array}{l}\text { Degrees } \\
\text { Celcius, } \\
\text { o } \mathrm{C}\end{array}$ & 28.0 & 25.4 & 25.0 & $15-30$ \\
$\mathrm{pH}$ & $\mathrm{pH}$ units & 6.4 & 6.6 & 6.6 & $6-9$ \\
$\mathrm{DO}$ & $\mathrm{mg} / \mathrm{L}$ & 0.3 & 0.39 & 0.45 & 5 \\
$\mathrm{BOD}$ & $\mathrm{mg} / \mathrm{L}$ & 200 & 210 & 194.33 & 30 \\
$\mathrm{TDS}$ & $\mathrm{mg} / \mathrm{L}$ & 984 & 922 & 934 & 500 \\
Nitrates & $\mathrm{mg} / \mathrm{L}$ & 18.23 & 21.48 & 20.5 & 10 \\
Phosphates & $\mathrm{mg} / \mathrm{L}$ & 1.35 & 0.98 & 1.18 & 0.5 \\
\hline
\end{tabular}

\subsection{Middle Manyame River General Water Quality}

Temperature and $\mathrm{pH}$ in the river water were within acceptable ranges. Generally, DO levels were in the decreasing order of May $>$ March $>$ November (Fig. 2) though there was no significant difference between the sampling campaigns (ANOVA: $\mathrm{p}>0.05$ ). Dissolved oxygen levels increased with increases in water flows (though not measured in the study) as a result of increased rainfall activity, with January and February being the peak rainfall months. Reference [2] showed that increased water flow results in increased turbulence and thus, re-aeration. In addition, warm conditions and more sunshine hours that prevail under dry weather conditions, as was in the month of November, promote evaporation of oxygen from the water into the air and more plant biological activity in the water resulting in dwindling DO [18]. It is shown in Fig. 3 that water 
temperatures were also highest in November. The sites just after effluent discharge from the respective adjacent sewage treatment plants

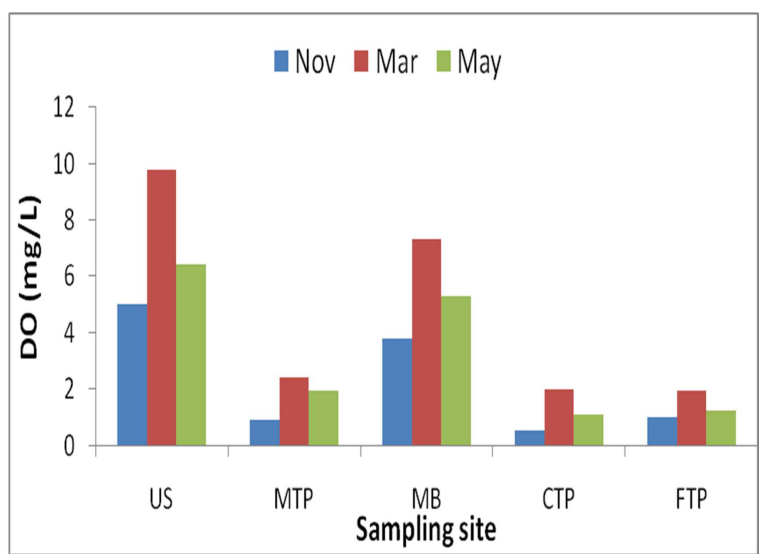

Figure 2. Variations in the DO levels along sites on Middle Manyame River.

(MTP, CTP, and FTP) had the lowest DO levels. The levels of DO registered at these sites were also below the recommended standard of between 4 and $5 \mathrm{mg} / \mathrm{L}$ required for normal biological activity, particularly, for prevention of detrimental effects to fish [18]. According to [19], presence of oxygen-demanding waste material, as at MTP, CTP, and FTP, which is decomposed by oxygen-consuming microorganisms, also further reduces DO in water.

On the other hand, the site before all the sewage effluent discharge points in Chinhoyi (US) had the highest DO levels of between $5 \mathrm{mg} / \mathrm{L}$ and $9 \mathrm{mg} / \mathrm{L}$. This scenario is consistent with less polluted sites.

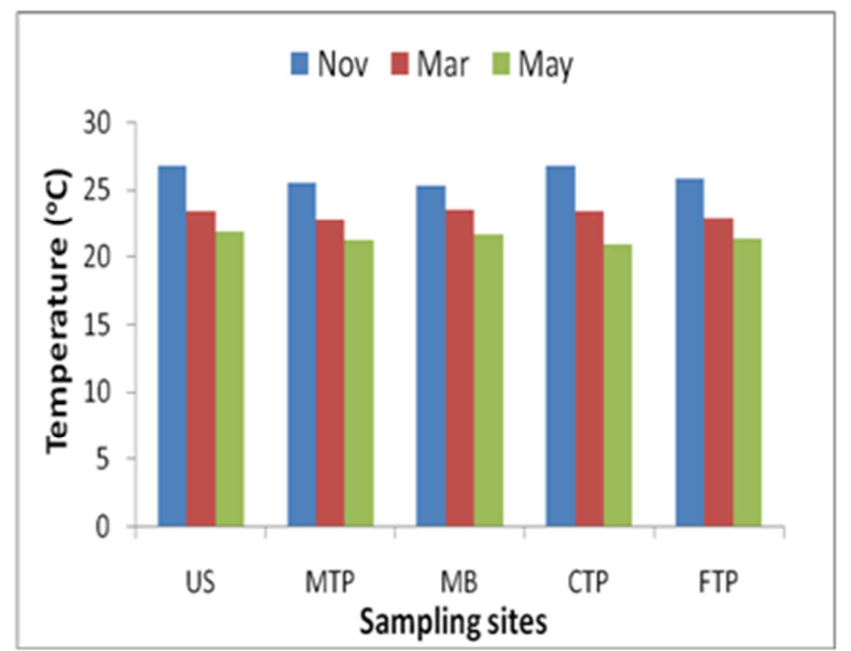

Figure 3. Variations in the temperature levels along sites on Middle Manyame River.

However, DO levels improved at MB, a site that is about $2.5 \mathrm{~km}$ from an effluent discharge site (MTP). This confirmed the availability of dilution and self-purification capacity that is existent in the river. The differences among the sites were significant (ANOVA: $\mathrm{p}>0.05$ ).

The pattern for TDS and BOD was the same and decreased in the following order: November (dry month) $>$ May $>$ March (wet month) as shown in Figs. 4 and 5, respectively. While the variations among these months were insignificant for TDS, they were significant for BOD levels. [20] also observed the same pattern on Ibadan River in Nigeria.

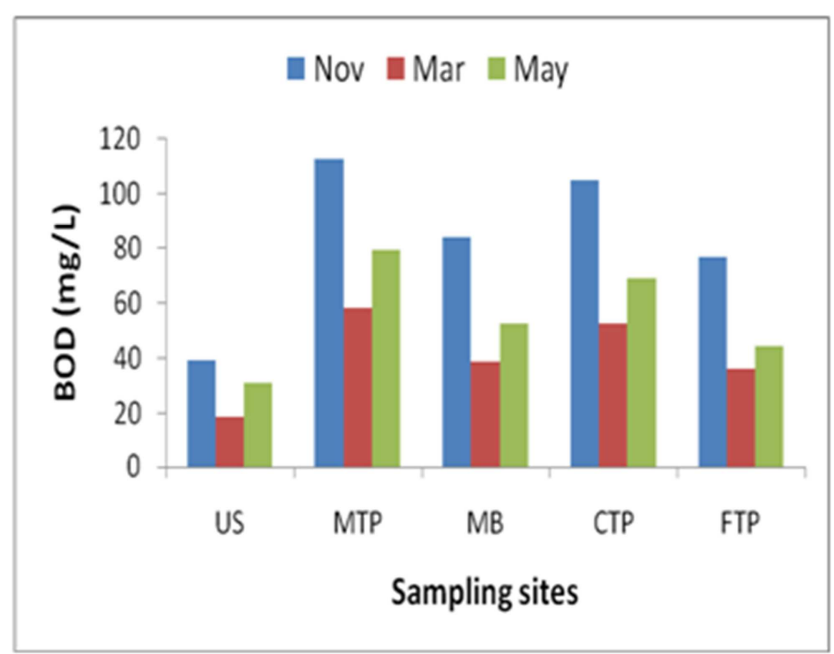

Figure 4. Variations in the TDS levels along sites on Middle Manyame River.

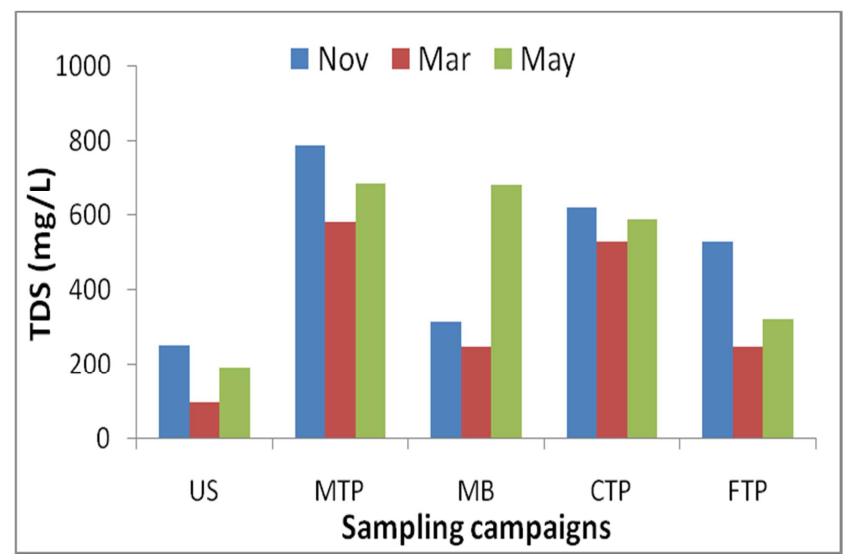

Figure 5. Variations in the BOD levels along sites on Middle Manyame River.

The month of March was characterized by increased water flows which increase availability of oxygen in the water for microbial activity hence low BOD in March and highest BOD in the drier month of November. The levels of TDS and BOD were highest at the effluent discharge sites, which is, at MTP, CTP and FTP further ascertaining the impact that the municipal discharge of untreated sewage effluent has on the water quality of Manyame River.

\subsection{Nutrient Status of Middle Manyame River}

Nitrate levels ranged from $6.42 \mathrm{mg} / \mathrm{L}$ at the control site in November to $15.86 \mathrm{mg} / \mathrm{L}$ at MTP in March (Fig. 6). There was a significant variation between sampling campaigns $(\mathrm{p}<0.05)$ with nitrate concentrations increasing as wet conditions enhanced. Nitrate levels were generally higher at the sites immediately after sewage disposal (MTP, CTP, and FTP) and lower at the control site, US (Fig. 6). 


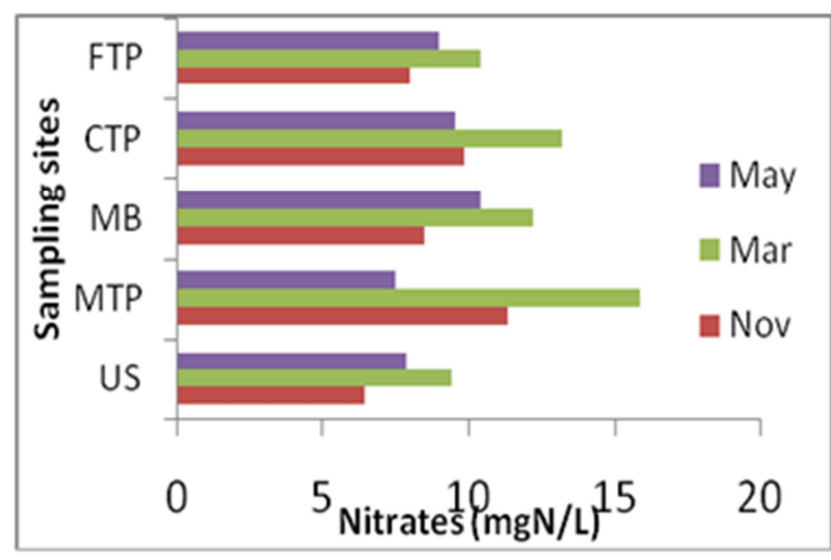

Figure 6. Variations in the nitrate $\left(\mathrm{NO}_{3}\right)$ levels along sites on Middle Manyame River in different sampling campaigns (Nov-November, MarMarch, May).

Total phosphates were also generally highest in the wettest month of the sampling period, that is, in March and lowest in November though these differences were insignificant as shown in Fig. 7. The highest concentration was recorded at MTP whilst the lowest was obtained from the control site just as for the nitrates. There was always an improvement in the nutrient content of Manyame River at the site which is at a distance from effluent discharge at MTP.

There are farms located along Manyame River upstream of Chinhoyi, and around the town of Chinhoyi. These include Portlet, Nicole, Hunnington and Gleensleeves with a total arable area above 2500 hectares under maize and other crops, as well as Chinhoyi University of Technology crop and livestock farm which is just adjacent the river. In addition, there are numerous gardening practices happening along the river. Fuelled by rainwater that washes off fertilizers from these farmed lands, agricultural runoff most probably had a huge contribution to nutrient levels in the river water, besides sewage effluent. References [13,21] also found the same results in their studies.

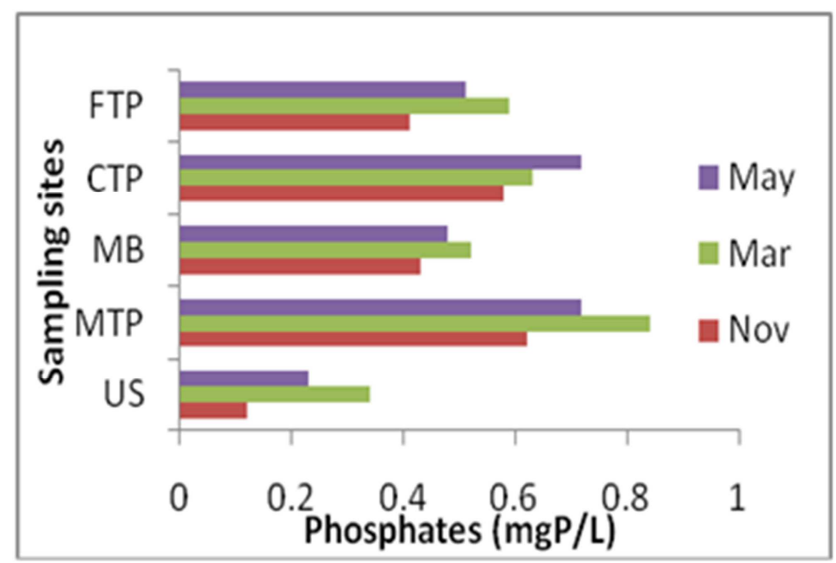

Figure 7. Variations in the phosphates $\left(\mathrm{PO}_{4}\right)$ levels along sites on Middle Manyame River in different sampling campaigns (Nov-November, MarMarch, May).

According to [22], nitrates in surface waters should range between $0.5 \mathrm{mg} / \mathrm{L}$ and $1.5 \mathrm{mg} / \mathrm{L}$ to avert the risk of eutrophication. All the sampling sites had nitrate levels above these limits hence the whole stretch of Middle Manyame River is at risk, if not already, impacted by eutrophication. As stipulated in [23], eutrophication-related problems in warm water aquatic systems begin to increase at ambient total phosphate (TP) concentrations exceeding 0.34 to $0.70 \mathrm{mg} / \mathrm{L}$. However, [24] specified that phosphate levels as low as 0.035 $\mathrm{mg} / \mathrm{L}$ to $0.10 \mathrm{mg} / \mathrm{L}$ are adequate to make a water body eutrophic. Therefore, according to [23] WHO (2006) standards, only the control site may be exempt from eutrophication-related problems whilst according to the latter standards all the sites can be considered eutrophic.

\section{Conclusion and Recommendations}

It was evident from the study that water quality in Middle Manyame river was severely impaired by the waste discharged from the various wastewater treatment plants. Middle Manyame River can be regarded as eutrophic though there is need for further studies to ascertain existence of this impairment. However, Middle Manyame River is still capable of self purification as shown by the decreases in the levels of most parameters as water flowed further downstream from the discharge points. Rehabilitation and upgrading of existing sewage systems by Municipality of Chinhoyi is strongly encouraged. Alternatively, recycling and/or reuse of the sewage for irrigation can be explored to alleviate the situation. There is need for a further study to investigate the self purification capacity of Manyame River as well as to ascertain existence of eutrophication.

\section{Acknowledgment}

Special thanks go to the Chinhoyi University of Technology for assistance with laboratory equipment that was used in sampling and analysis. Particular mention goes to Mr Tendaupenyu, Nobuhle Ndebele, and Alpha Machava for their aid in sample collection.

\section{References}

[1] Kuang, Q; Bi. Y; Xia. Y and Hu. Z (2004). Phytoplankton community and algal growth potential in Taipinhu reservoir, Anhui Province, China, Lakes \& Reservoirs: Research \& Management. 9(2): 119-124.

[2] Akpor O. B. and Muchie, M. (2011) Environmental and public health implications of wastewater quality. Afr $\mathrm{J}$. Biotechnology 10(13): 2379-2387.

[3] Shirajavu H.P (2011), Impact Assessment of Sewage Discharge on Underground Water Qualities around Municipal Sewage Treatment Plant (Mysore City, India). Int. J. Res. Chem. Environ. 1(2):28-35.

[4] Chimanga J.R, (2010) Impact of industrial effluent from an iron and steel company on the physicochemical quality of Kwekwe River water in Zimbabwe .International Journal of Engineering Science and Technology (2): 129-140. 
[5] Nhapi I and Tirivarombo S (2004). Sewage discharges and nutrient levels in Marimba River, Zimbabwe. WaterSA, 30 (1):107-113.

[6] Mudozori G and Kusangaya S (2011). Analysis of the challenges posed by water pollution in providing standard water quality: The case of Chinhoyi urban, Zimbabwe(Unpublished).

(http://www.waternetonline.ihe.nl/downloads/uploads/symposi um2005/theme2/Kusangaya\%201.pdf)

[7] Welch E.B and Lindell T (1980). Ecological effects of waste water. Cambridge University Press, London, United Kingdom.

[8] Eynard F, Mez K, Walther J.L (2000). Risk of cyanobacterial toxins in Riga waters (LATVIA). Water Res. 30(11): 29792988.

[9] Mbewele L (2006). Microbial phosphorus removal in wastewater stabilization pond. A Licentiate Thesis from the School Biotechnology: A Royal Institute of Technology.

[10] Amir H.M, Ali R.M, Farham K (2004). Nitrogen removal from wastewater in a continuous flow sequencing batch reactor. Pak. J. Biol. Sci. 7(11): 1880-1883.

[11] Gohil, M.B., 2000, Land treatment of wastewater. New Age International (p) Ltd, Publishers, New Delhi, India.

[12] Wuta M, Muisa N, Misi S. and Nyamangara J (2007). The impacts of Sewage Effluent on the Physico-chemical quality of Chinyika River (Unpublished Bsc Thesis) Department of Soil Science and Agricultural Engineering, University of Zimbabwe.

[13] Bere T, (2005) The impact of Sewage Effluent and Natural Self-Purification in the Upper Chinyika river below Hatcliffe Sewage Works, MSc thesis (Unpublished), University of Zimbabwe.

[14] Compendium of Statistics 2012, Zimbabwe.
[15] Tendaupenyu P, 2012, Nutrient Limitation of Phytoplankton in Five Impoundments on Manyame River, Zimbabwe, MSc Thesis (Unpublished) University of Zimbabwe.

[16] American Public Health Association (APHA). 2005. Standard Methods for the Examination of Water and Wastewater. 21st Edition. APHA, Washington, D.C.

[17] Zimbabwe National Water Authority (cited as ZINWA). (2000). Operational Guidelines for the Control of Water Pollution in Zimbabwe, 2000. Harare, Zimbabwe: Government Publishers.

[18] Metcalf \& Eddy, Inc., 1995. Wastewater Engineering: Treatment, Disposal and Reuse, $3^{\text {rd }}$ ed. Tata McGrawHill Co. Ltd., New York, USA.

[19] Department of Water Affairs and Forestry (DWAF), 1996. South African Water Quality Guidelines, Aquatic Ecosystems, vol. 7. Holmes, S. (Ed.), CSIR. Environmental Services, Pretoria 0001, Republic of South Africa.

[20] Adeyemo O.K, Adedokun O.A, Yusuf R.K and Adeleye E.A ; 2008; Seasonal Changes in Physico-Chemical Parameter and nutrient load of River Sediments in Ibadan city Nigeria; Global NEST Journal.

[21] Masere, T.P., Munodawafa, A. and Chitata, T. (2012), "Assessment of human impact on water quality along Manyame River", International Journal of Development and Sustainability, Vol. 1 No. 3, pp. 754-765.

[22] Walk, M.F. (2004) Chloride. High pH. Nitrogen. Phosphorus. Massachusetts Water Watch Partnership (2004). Fact Sheets.

[23] WHO (2006). Guidelines for the Safe Use of Wastewater, Excreta and Greater, vol. 3. World Health Organisation Press.

[24] CCME (Canadian Council of Ministers of the Environment), 2003. Canadian Water Quality Guidelines for the Protection of Aquatic Life: Aluminium. 